喉頭 $20: 117 \sim 122,2008$.

\title{
当科における咽喉頭食道異物症例の検討
}

\author{
宇 野 光 祐 - 齋 藤 康一郎 - 稲 垣 康 治 - 長 西 秀 樹 \\ 小川郁
}

Clinical Observations on Patients with Laryngopharyngoesophageal Foreign Bodies

\author{
Kosuke Uno, Koichiro Saito, Koji Inagaki, \\ Hideki Naganishi and Kaoru Ogawa
}

\begin{abstract}
Clinical investigations were performed on 129 cases that had been referred to our clinic with the complaint of foreign bodies in the throat between November 2006 and October 2007. Foreign bodies were found in 83 cases (64\%) and the most common materials were fish bones (73 cases; 88\%), notably eel bones. In children, most of the foreign bodies were fish bones in the oral cavity, in the palatine tonsil or at the root of the tongue. In the elderly, press through package (PTP) was considered to be another common material other than fish bones and was found mainly at root of the tongue, in the hypopharynx or in the esophagus. Most of the foreign bodies were easily removed under direct vision $(87 \%)$ or under flexible endoscopy $(7 \%)$. We had one patient with a self inserted acupuncture needle into supraglottic lesion that required direct laryngoscopy under general anesthesia to successfully remove the item. Our study suggests that age is an important factor to estimate the position of a foreign body. Although none of the non-detectable cases turned out to have a foreign body in an extrapharyngeal lesion in this study, we consider it important to perform the careful examination and intensive follow up of the patients even when foreign bodies are not detectable during their first visit.
\end{abstract}

Key words：異物, 統計, 喉頭, 鍼, 魚骨

は じめに

咽喉頭食道異物は耳鼻咽喉科の日常診療において高い頻 度で遭遇する疾患のひとつである. 成人患者が食物摂取直 後から違和感を訴えて受診する場合, 異物内容も明らかな ことが多いが，異物が気道に存在する場合や，鋭利な異物 の場合など，管理や摘出に注意が必要なケースもある．介 在部位も口蓋扁桃や舌根扁桃がほとんどであることは知ら れており, 摘出方法もほとんどの症例では外来診療中に直 視もしくは内視鏡で観察しながら鉗子で摘出できる。しか しながら，患者の状態，異物の介在部位によっては全身麻 酔下での摘出が必要となる場合もあり, 外切開を行っての 摘出が必要であったという報告も散見され, 注意が必要で ある。また食物摂取後からの強い咽頭違和感など, 患者の 訴えからは異物の存在が強く疑われるものの, 来院時に慎 重に診察しても異物を確認できず診断に苦慮する症例もま れではない.

今回我々は当大学病院耳鼻咽喉科外来を咽喉頭食道異物 疑いにて受診した症例について臨床的検討を行ったので, 文献的報告を加えて報告する。 また，この観察期間に，比 較的珍しいと考えられる, 頸部より誤刺入された鍼治療用 の鍼が喉頭異物となった一症例を経験したのであわせて報
告する。

\section{対象と方 法}

2006年11月から 2007 年10月の 1 年間に咽喉頭食道異物疑 いにて当院耳鼻咽喉科を外来受診した129例を対象とした。 診療録をもとに, 年齢, 性別, 異物内容, 異物の介在部位 ならびに摘出方法につき検討したが，成人例では喉頭銊異 物の一例以外では, 食物や薬物を嚥下直後からの咽頭違和 感または咽頭痛を主訴に受診していた．小児の異物例（魚 骨, ビニール袋, 玩具) では親の目撃証言や, 本人の咽頭 痛が主訴であった。

\section{結 果}

\section{1. 年齢と性別, 受診の時間帯}

男性 59 人，女性 70 人の計 129 人が受診したが，実際に異 物を確認し得た症例は 129 例中 83 例 $(64 \%$ ：男性34人，女 性49人) であり，これらの症例においては，全例異物を摘 出可能であった。 また確認し得なかった症例は, 発熱や疼 痛の持続・増悪等の自覚症状を認めた場合は医療機関を必 ず再度受診するよう説明されていた。平均年齢は34.7歳 （７ケ月～93歳）で，年齢別では 9 歳以下と $30 \sim 39$ 歳に多 く，二峰性を示した（図 1)。また，129例中114例（88\%） 
が，夕方 17 時までの外来日勤帯以後の受診であった。

2 . 異物内容

異物内容の内訳は魚骨が73例 $(88 \%)$ と圧倒的に多く, 魚骨が特定できた52例の魚種の内訳は，ウナギ30例，サバ 5 例，アジ 5 例，サンマ 4 例，サケ 2 例で，その他イサキ， イワシ，カッオ，コマイ，サワラ，トビウオがそれぞれ 1 例であった。次いで PTP が 3 例，その他 7 例（ビニール 袋，縫製用の針，鍼炎治療用の銊，玩具，茶筅，梅干の種，

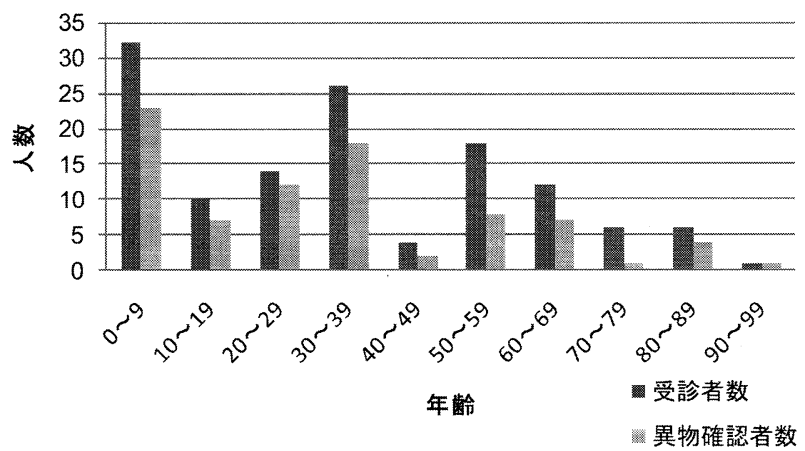

図 1 患者の年齢別分布

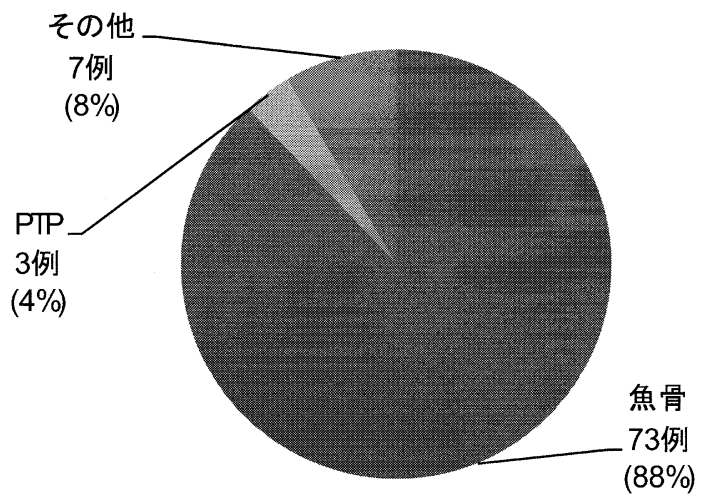

図 2a 異物内容 (83例)

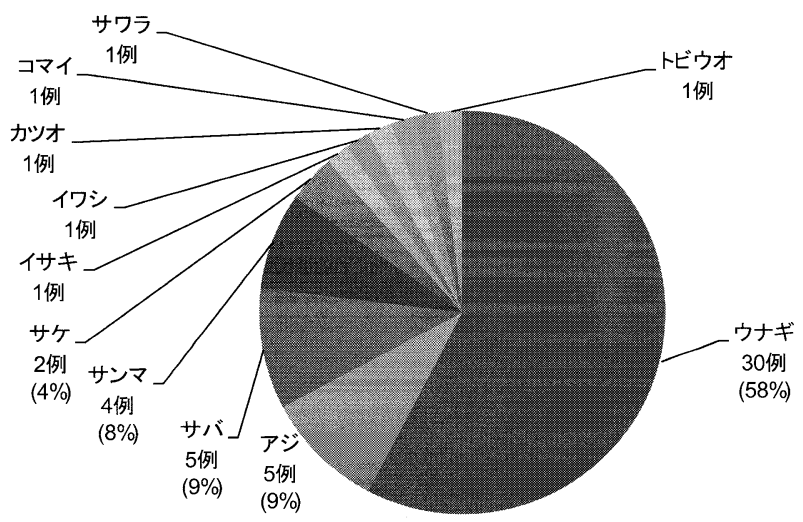

図 $2 b$ 魚骨 (52例) の内訳
食物残渣) であった（図 $2 \mathrm{a}, \mathrm{b})$ ）小児例では玩具やビニー ル袋などの食物以外のものを不用意に口に入れてしまった 結果に起こりえる異物が特徴的で, PTP や食物残渣は高 齢者に多い傾向が認められた（表 1 ）.

3. 異物の介在部位

介在部位は口蓋扁桃が53例 (魚骨), 次いで舌根扁桃が 20例（魚骨18例，針 1 例，茶笔 1 例）と多くみられ，それ らで全体の 9 割弱を占めていた．その他の介在部位として， 喉頭蓋舌面に2 例 (魚骨), 下咽頭に 2 例（梅干しの種, 食物残渣), 口腔内に 2 例 (玩具, ビニール袋), 喉頭に 1 例 (鍼)，さらに食道に異物 (PTP) が存在した症例が 3 例認められた（図 $3 \mathrm{a}$ )。異物の中で圧倒的に多くみられた 魚骨（73例）においての介在部位は，口蓋扁桃が53例，舌 根扁桃が18例，喉頭蓋舌面が 2 例であった（図 $3 b)$ ．年歯令 による介在部位の特徵として，小児では異物が口腔内から 舌根にかけて介在している傾向がみられた一方で，高齢者 では，舌根から食道にかけて介在する傾向がみられた（表 2a).

表 1 異物内容と年齢の関係

\begin{tabular}{|c|c|c|c|c|c|}
\hline 年齢 & 魚骨異物 & PTP & & 刀他 & 計 \\
\hline $0 \sim 9$ & 21 & 0 & 2 (玩具, & ビニール袋） & 23 \\
\hline $10 \sim 19$ & 6 & 0 & & 0 & 6 \\
\hline $20 \sim 29$ & 13 & 0 & & 0 & 13 \\
\hline $30 \sim 39$ & 18 & 0 & & 0 & 18 \\
\hline $40 \sim 49$ & 1 & 0 & & 1 (針) & 2 \\
\hline $50 \sim 59$ & 7 & 0 & & 1 (鍼) & 8 \\
\hline $60 \sim 69$ & 5 & 1 & & 1 (茶笔) & 7 \\
\hline $70 \sim 79$ & 0 & 1 & & 0 & 1 \\
\hline $80 \sim 89$ & 2 & 1 & & 1（梅干の種） & 4 \\
\hline $90 \sim 99$ & 0 & 0 & & 1 (食物残渣) & 1 \\
\hline 計 & 73 & 3 & & 7 & 83 \\
\hline
\end{tabular}

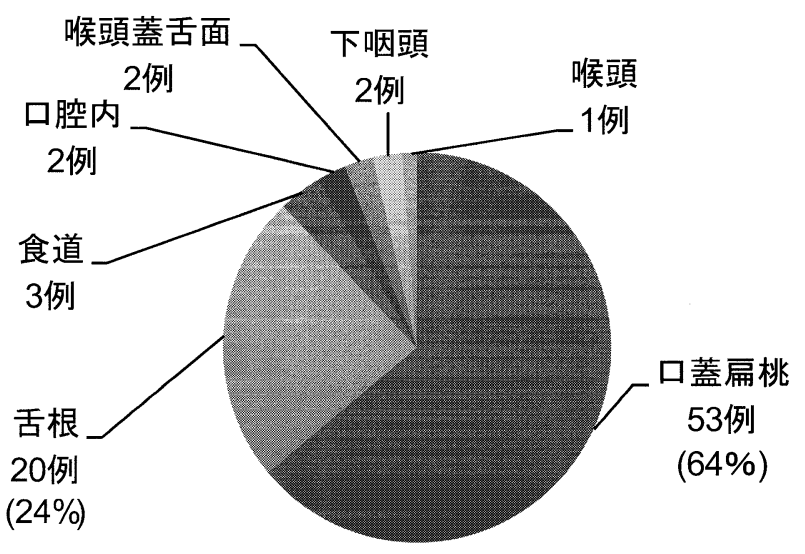

図 3a 異物（83例）の介在部位 


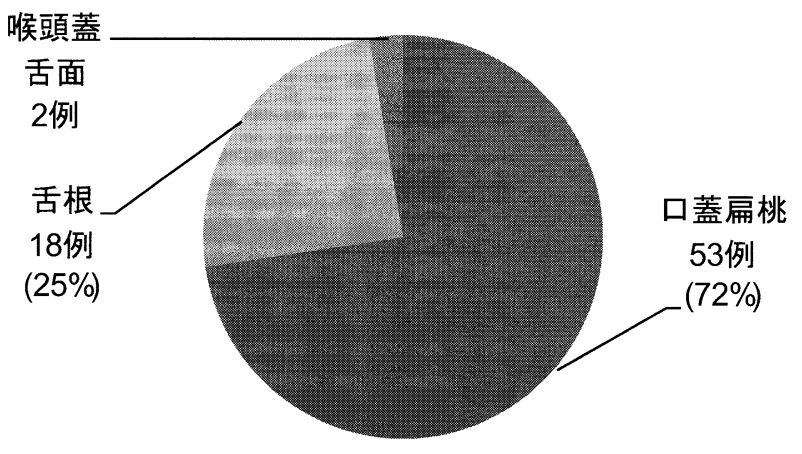

図 $3 b$ 魚骨 (73例) の介在部位

表 $2 \mathrm{a} \quad$ 介在部位と年齢の関係

\begin{tabular}{crrrrrrrr}
\hline \hline 年齢 & 口蓋扁桃 & 舌根 & 食道 口腔内 & $\begin{array}{c}\text { 喉頭蓋 } \\
\text { 舌面 }\end{array}$ & 下咽頭 & 喉頭 & 計 \\
\hline $0 \sim 9$ & 19 & 2 & 0 & 2 & 0 & 0 & 0 & 23 \\
$10 \sim 19$ & 4 & 2 & 0 & 0 & 0 & 0 & 0 & 6 \\
$20 \sim 29$ & 10 & 3 & 0 & 0 & 0 & 0 & 0 & 13 \\
$30 \sim 39$ & 14 & 3 & 0 & 0 & 1 & 0 & 0 & 18 \\
$40 \sim 49$ & 1 & 1 & 0 & 0 & 0 & 0 & 0 & 2 \\
$50 \sim 59$ & 3 & 3 & 0 & 0 & 1 & 0 & 1 & 8 \\
$60 \sim 69$ & 1 & 5 & 1 & 0 & 0 & 0 & 0 & 7 \\
$70 \sim 79$ & 0 & 0 & 1 & 0 & 0 & 0 & 0 & 1 \\
$80 \sim 89$ & 1 & 1 & 1 & 0 & 0 & 1 & 0 & 4 \\
$90 \sim 99$ & 0 & 0 & 0 & 0 & 0 & 1 & 0 & 1 \\
\hline 計 & 53 & 20 & 3 & 2 & 2 & 2 & 1 & 83 \\
\hline
\end{tabular}

\section{4. 摘出方法}

口蓋扁桃, 舌根扁桃, 喉頭蓋舌面, 口腔内に介在した異 物は，直視下，間接喉頭鏡下，または鉗子チャンネル付鼻 咽喉ビデオスコープ経由に鉗子を用いて摘出した。なお， 摘出した異物の多くを占めた魚骨73例のうち，70例は直視 下.間接喉頭鏡下での摘出, 2 例はビデオスコープ下での 摘出, 1 例は摘出方法不明であった。 下咽頭, 食道異物 （PTP 3 例, 食物残渣 1 例）は咽頭麻酔を行い, 下咽頭 ファイバーまたは上部消化管内視鏡を用いて摘出した。ま た梨状陥凹に介在した例では，診察時の嘔吐反射により患 者が自ら異物（梅干の種）を嘔吐し, 自然排出された。今 回検討した期間に，外切開を要した症例はなかったが，喉 頭鍼異物（鍼炎治療用の銊）の一例に対しては全身麻酔下 に直達喉頭鏡を用いて摘出した（図 4). 以下，この喉頭 鍼異物の一症例を提示する。

〈症例〉55歳 男性 鍼尒師

〈主訴〉のどの違和感

〈現病歴〉2007年10月21日, 患者自身が，自らの頸部に 鍼を刺入した際, 皮下に鍼が迷入し, 直後からのどの違和 感が出現した。 その後食事をとったが, 症状が改善しなかっ

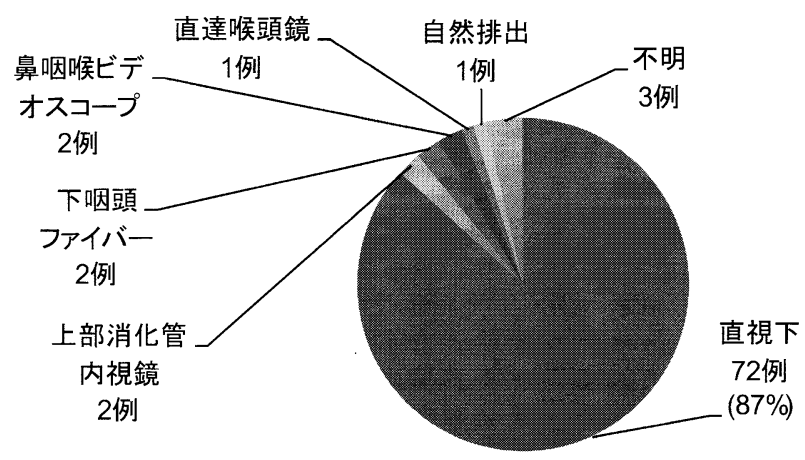

図 4 摘出方法

たため, 同日近医耳鼻咽喉科を受診した。頸部単純 X 線 写真を撮影したところ，金属と思われる陰影を頸部に認め たため, 加療目的で同日深夜当院へ救急搬送された.

〈入院時所見〉

来院時, 発熱や呼吸苦はなかったが, 発声時の強いのど の違和感を認めた。頸部に皮下気腫や熱感, 発赤は認めず, 本人が刺入部と訴えた右下顎角一横指下にも，体表からは 傷は確認できず，異物も触知できなかった，頸部単純 X 線写真では舌骨下端の高さに, $4 \mathrm{~cm}$ 大の細い金属影を認 め, 精査目的に撮影した頸部 CT では鍼の先端は左披裂部 内に嵌入していた。頸部に膿瘍, 気腫は認められなかった (図 5). 鼻咽喉ビデオスコープでも, 喉頭内に介在し, 声 門上を披裂部の高さで横断する銊を認めた（図 $6 \mathrm{a}$ )。細い 異物で, 介在部位が喉頭であることから, 不用意な摘出を 行うと, 異物の気道への落下のリスクがあり，また鋭利な 異物の摘出には慎重な操作が必要と考えられたことから, 局所麻酔下での経口的摘出は困難かつ危険と判断し, 経口 掑取・発声を禁止としてステロイドの点滴投与を行った上， 翌朝全身麻酔下での緊急異物摘出術を施行した。麻酔医に よる慎重な経口気管内挿管の後, 直達喉頭鏡下に喉頭を観 察すると, 喉頭蓋下方を披裂部の高さで横断する鍼を容易 に確認できた。患者が持参した，誤刺入されたものと同一 の鍼が，非常に柔らかく弾性に富む物性であったことから， 喉頭内視鏡下微細手術に用いる麦粒鉗子で銊の中央を把持 して慎重に引き抜いたところ, 鍼はしなりながら容易に摘 出でき, 出血も認めなかった. 摘出した鍼は長さ $40 \mathrm{~mm}$, 径 $0.25 \mathrm{~mm}$ と非常に細いステンレス製のものであった（図 $6 \mathrm{~b})$. 患者の持参した鍼と摘出物を比較し, 鍼は欠けるこ となく全摘されたことを確認した，術後違和感は消失し， 翌日軽快退院となった。

\section{考察}

\section{1. 受診の時間帯}

今回の検討では，129例中 114 例（88\%）が時間外受診で あった．平日の日勤帯においては自宅あるいは職場近医の 耳鼻咽喉科を受診可能であるが, 夜間では時間外対応を行っ ている大学病院などの施設に受診せざるを得ないためであ 

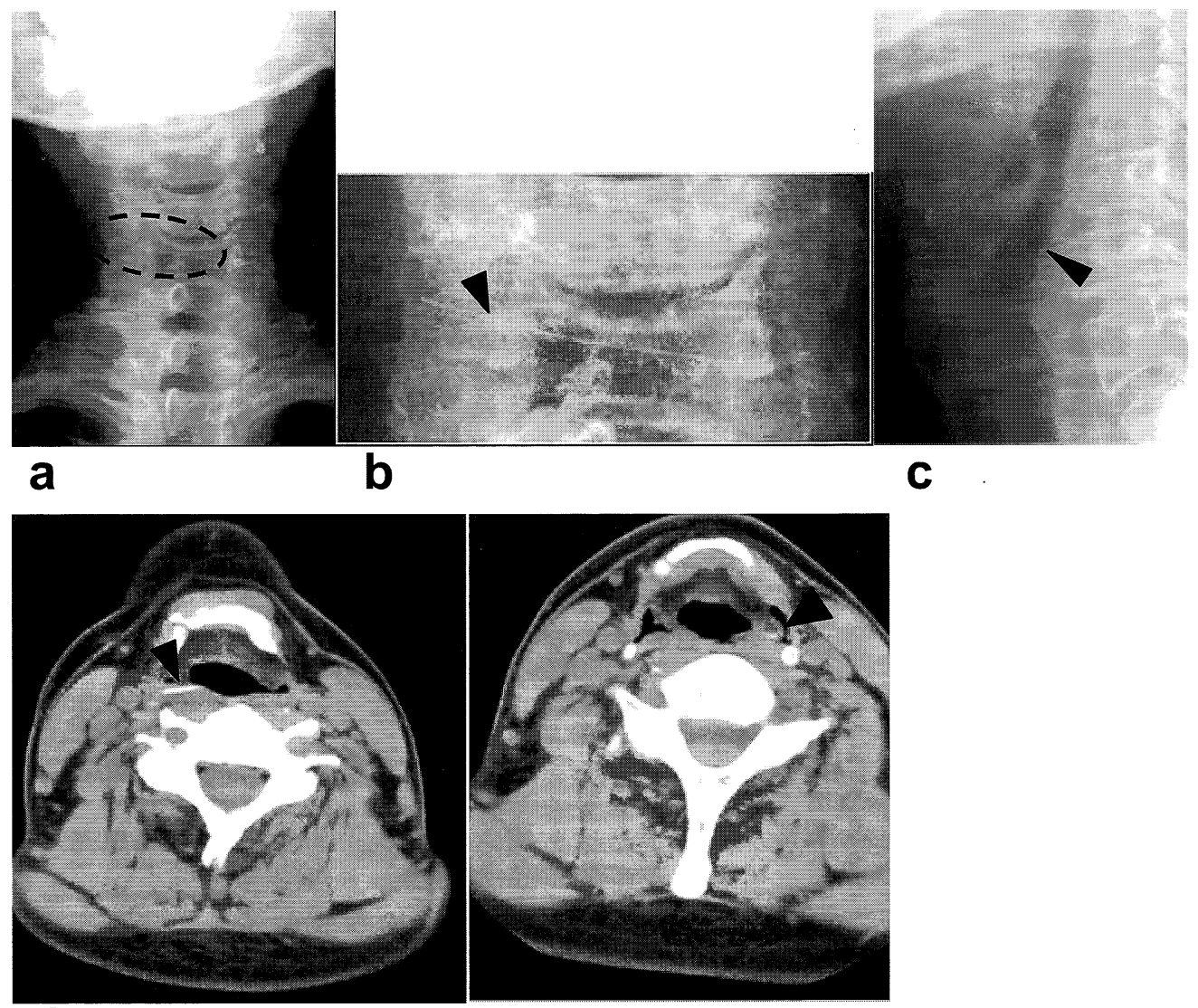

d

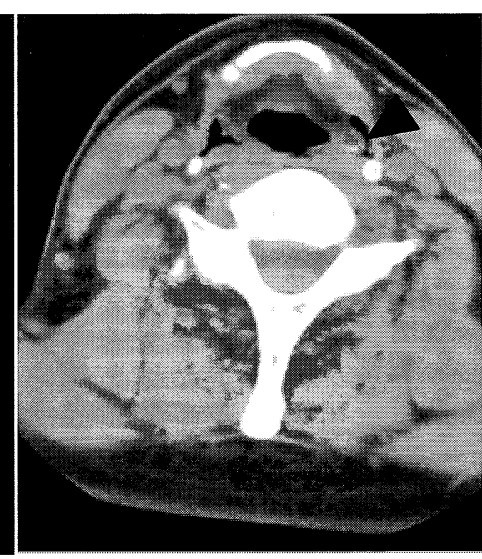

C

図 5 a : 頸部単純 X 線写真正面像. 頸部の点線で囲んだ部位に細い金属影を認める. $\mathrm{b} ： \mathrm{a}$ の異物部分を拡大したイメージを示す (矢頭：鍼) $c ：$ 頸部単純 X 線写真側面像 (矢頭：銊). $\mathrm{d}, \mathrm{e}$ : 頸部単純 CT. 右頸部から刺入された銊は舌骨の高さで喉頭を横断しており，先端は左披 裂部内に嵌入していた.

ると思われる。また朝食，昼食と比べ，一般的に夕食は摂 取量が多い傾向にあることも関係しているのではないかと 考える.

\section{2 . 年齢分布}

年齢別受診者数は10歳未満と30代が多い二峰性を示した。 これまでにも同様の傾向が報告されている1).10歳未満の 小児に多い理由としては口蓋扁桃の生理的肥大や誤って口 に物をいれてしまうことが原因となっている可能性がある. 30 代の患者は他の年代に比べ, 食事摂取量が比較的多いこ とや，日中は職場での勤務中のため, 時間外の受診に頼ら ざるを得ないことも, 夜間来院が多く認められた本検討の 結果と併せて考えると, 理由のひとつとして考えられる. 3. 異物内容

異物内容はこれまでの報告 ${ }^{1 \sim 4)}$ 同様，魚骨が73例と最も 多く，全異物の約 $88 \%$ を占めていた。異物内容と年齢の関 係（表 1) ではPTP が，高齢者に集中していたことが特 徵的であった。この理由として，他の年代に比べ内服薬が 多いことや，咀嚼機能・唾液分泌能が低下していることが 理由として考えられている ${ }^{5,6)}$. なお, 我々は以前, 自覚
症状掞よび画像所見から, 食道外魚骨異物を疑い頸部外切 開により試験開放したところ，石灰化した鎖骨下動脈の走 行異常であった症例を経験した。臓器の石灰化も除外診断 の項目として考慮すべきと考えさせられた経験であった。

4. 介在部位

異物内容として最多であった魚骨における介在部位は口 蓋扁桃53例 $(72 \%)$, 次に舌根部18例 $(25 \%)$ であったが, この割合は従来からの報告と同様である ${ }^{3-5)}$. 口側により 近い部位に異物が介在する傾向があるのは自然なことと思 われ，実際に臨床現場で異物を探索する際は，口蓋扁桃， 舌根扁桃を入念に観察した後, 喉頭, 下咽頭から食道の観 察に移行するほうが効率がよいと考えられる。

介在部位と年齢の関係（表 2a）を検討したところ，小 児では異物, 特に魚骨が口腔内から舌根にかけて介在し, 高齢者では魚骨やPTP などの異物が舌根から食道にかけ て介在する傾向がみられた。览において口側に異物が多 かった原因としては，扁桃の生理的肥大が原因のひとつと 考えられる。この年龄による介在部位の偏る傾向は, 診察 の際におおよその介在部位を予想する上で有用と思われる。 

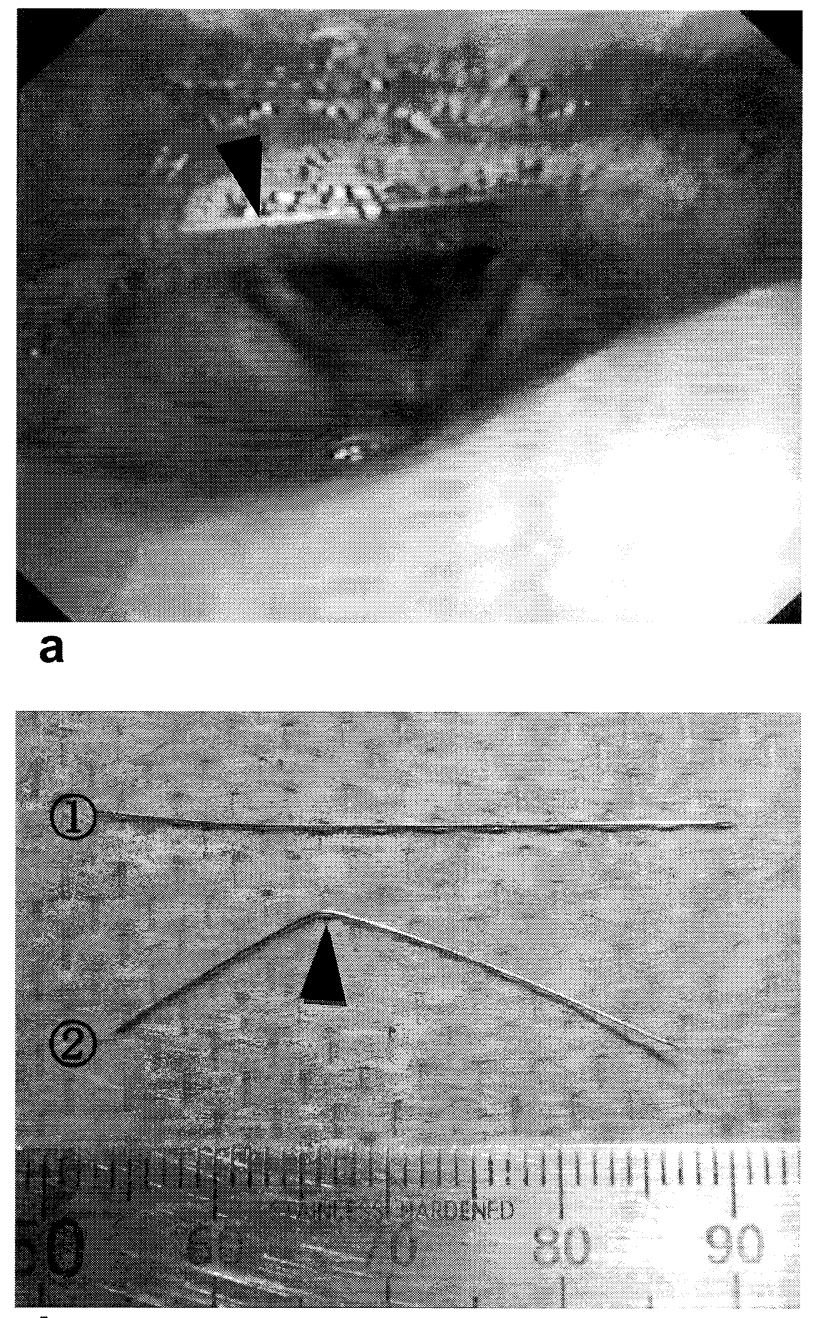

b

図 $6 a \mathrm{a}$ ：鼻咽喉ビデオスコープ所見. 喉頭を横断し， 披裂部に嵌入する銊を認めた (矢頭).

b : (1)誤刺入した鍼と同一の鍼治療用の鍼. 長 径約 $4 \mathrm{~cm}$, 直径 $0.25 \mathrm{~mm}$.

(2)摘出した鍼. 矢頭は鉗子で把持した部分.

また，今回異物内容として多かった魚骨のみに関して，介 在部位と年齢（表 $2 b ）$ を比較検討したが, 今回の検討で は高歯者における魚骨異物症例が少なかったためか, 年歯 による明らかな差異は認めなかった。

5. 異物が確認できなかった症例

実際に異物を確認し得た症例は全129例中83例（64\%） であった．言い換えれば，異物疑いにて受診した患者のう ち約 $1 / 3$ は異物を確認し得なかった。 その理由として, 異 物が消化管の下方に落下し異物感のみ残存した可能性や, 違和感出現後も食事を続けたために異物が粘膜内に押し込 まれ埋没した可能性が考えられる。 また, いわゆる咽喉頭 異常感症の患者が, 異物の可能性を訴えて受診したことも 考えられる.今回経過観察した症例にはなかったが, これ までには, 抗菌剤で経過観察されたにも関わらず食道周囲 膿瘍を形成するまでに悪化した魚骨異物による食道穿孔
表 $2 b \quad$ 魚骨の介在部位と年齢の関係

\begin{tabular}{ccccc}
\hline \hline 年齢 & 口蓋扁桃 & 舌根 & 喉頭蓋舌面 & 計 \\
\hline $0 \sim 9$ & 19 & 2 & 0 & 21 \\
$10 \sim 19$ & 4 & 2 & 0 & 6 \\
$20 \sim 29$ & 10 & 3 & 0 & 13 \\
$30 \sim 39$ & 14 & 3 & 1 & 18 \\
$40 \sim 49$ & 1 & 0 & 0 & 1 \\
$50 \sim 59$ & 3 & 3 & 1 & 7 \\
$60 \sim 69$ & 1 & 4 & 0 & 5 \\
$70 \sim 79$ & 0 & 0 & 0 & 0 \\
$80 \sim 89$ & 1 & 1 & 0 & 2 \\
$90 \sim 99$ & 0 & 0 & 0 & 0 \\
\hline 計 & 53 & 18 & 2 & 73 \\
\hline
\end{tabular}

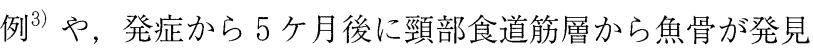
された症例 ${ }^{7)}$, 咽頭腔外魚骨異物例で半年ほど無症状であっ た症例も報告されている ${ }^{8)}$ ため, 注意が必要である。従っ て, 異物を確認し得なかった患者に対しては, 発熱や違和 感の持続, 頸部腫脹などの明らかな臨床症状の増悪を自覚 した場合には必ず再度受診し，精査をうけるように勧めて いる。 また，初診時に異物の存在が確認できない場合でも， 異物が潜在している可能性がある旨を患者に伝えておくこ とは，リスクマネジメントの観点からも重要と考える。な お，今回の検討では，一旦帰宅後に再度当科を受診し，改 めて受診した際に異物が発見された症例はなかった。

\section{6 。喉頭異物}

喉頭異物は比較的稀な異物であり, 文献 ${ }^{4)}$ 上はボタンや コインなどが小児に多くみられると報告されている。今回 報告した症例は頸部から患者自身が異物を刺入した極めて 稀な一例である。これまでにも，鍼尒針の伏針は臂部や後 頸筋での報告はあるが9), 著者が検索した範囲では，側頸 部からの報告はない.

一般に文献的に咽喉頭食道異物に対する外切開の適応と して，1）直視下，内視鏡下に摘出不可能な下咽頭食道腔 外異物例，2）膿瘍を形成している例，3）摘出時に粘膜， 大血管を損傷する可能性のある症例があげられてい る $^{10 \sim 13)}$.

当科で今回経験した喉頭鍼異物の症例では，異物の介在 部位から，直達喉頭鏡下で異物を明視下におくことが十分 可能と考え，また鍼の両端が大血管に接触していないこと や，明らかな膿瘍形成が無いことを内視鏡検査や画像診断 にて確認した．さらにまた患者自身の持参した，誤刺入し たものと同一の鍼をチェックしたところ，非常に柔軟性に 富む柔らかな金属であったため慎重に摘出すれば周囲の血 管や粘膜を不用意に傷つけずに経口的に摘出可能と判断し たうえで手術を施行し，実際直達喉頭鏡下に安全かつ容易 に摘出可能であった，なお，経口挿管に関しては，鍼の位 置が喉頭後方の披裂部付近であることを麻酔科医に伝え， 喉頭内腔の前方へ慎重に気管内挿管することで, 安全な気 
道確保が可能であった.

$$
\text { ま と め }
$$

2006年11月から 2007 年10月の 1 年間に咽喉頭食道異物疑 いにて慶應義塾大学病院耳鼻咽喉科を外来受診した 129 例 につき, 臨床的検討を行った. 年齢別受診者数は 10 歳未満 と30代が多い二峰性を示した．異物内容は魚骨が多く，な かでもウナギの骨が最多であった. 介在部位では口蓋扁桃, 次いで舌根扁桃に多くみられ，特に小児では魚骨が口腔内 から舌根にかけて介在し，高齢者では魚骨や PTP が舌根 から食道にかけて介在する傾向が認められた。臨床現場に おいて，患者の年歯，異物内容から介在部位の㧍拉よその 見当をつけた上で，重点的に観察することが有用であろう.

食物や薬物を嚥下後に咽喉頭食道違和感を訴え当院に外 来受診した症例のうち, 異物を確認し得たのは全患者の64 \%であった，異物の物性や位置によっては，重篤な経過を たどった報告もあることから，来院時に異物の種類や材質， 特徵などの問診を十分に行い，患者の状態を的確に判断し た上で迅速かつ適切な診断と処置を行うことが重要である ことは勿論, 確認できなかった症例に対しても, 慎重な対 応が重要と思われる。

なお，本論文の要旨は，第20回日本喉頭科学会（2008年 3 月，佐賀）にて発表した。

\section{参 考 文 献}

1）松井利憲，山田恭子，村松裕子ほか：当院における 異物症例の臨床統計的観察.耳鼻臨床 89(1)：95 101, 1996.

2）奥 雅哉, 折田洋造，秋定 健ほか：当科における 異物症例の検討. 耳鼻臨床 補96：194〜 198, 1998.

3）佐藤文彦：耳鼻咽喉科領域の各種異物一過去 10 年間 の集計から一。京都医学会雑誌 $51(2)$ : 53〜 59,
2004.

4）高山靖史，久保正治，岡部宇彦：過去 5 年間の当科 における異物症統計。南大阪医学 51(1)：93～99, 2003.

5）楢村哲生，竹村考史，佐生秀幸ほか：当科における 魚骨異物症例の検討。耳喉頭頸 $80(2) ： 149 \sim 152$, 2008.

6）木村裕毅, 竹山 豊, 横山 隆ほか：魚骨異物の 2 症例一咽頭および食道腔外異物一。日気食会報 47 (4) : 391 397, 1996.

7）山下 勝, 平野 滋, 金子賢一ほか: 陳旧性の食道 腔外異物例。日気食会報 $53(1) ： 45 \sim 48,2002$.

8）北村守正, 結城和央, 林 正彦ほか：長期嵌在した 咽頭腔外魚骨異物例。耳鼻臨床 92(11)：1217～ 1220, 1999.

9）後藤龍学, 前田. 求, 桑江克樹ほか：X 線透視下に 摘出が行われた銊尒針の 5 例. 日形会誌 $26: 383$ 387, 2006.

10）中村一博, 吉田知之, 鈴木伸弘ほか：頸部外切開に て摘出した下咽頭食道異物症例の検討。日気食会報 57(3) : 298 306, 2006.

11）塚原清彰，渡嘉敷亮二，鈴木 衛ほか：食道異物症 と診断. 手術. JOHNS 19(9)：1371 1374， 2003.

12）長山郁夫, 丸山裕美子, 嶋田武文ほか：危険間隙ま で達した魚骨の 1 例一頸部外切開を要した咽頭異物 の 1 例一。日気食会報 $45(6): 437 \sim 441,1994$.

13）友田智哲, 片岡英幸, 鈴木幹夫ほか：外切開を要し た咽頭腔外異物 2 症例。耳鼻臨床 $92(7) ： 763 \sim 768$, 1999.

別刷請求先 $=160-8582$ 東京都新宿区信濃町 35 慶應義塾大学医学部耳鼻咽喉科学教室

宇野光祐 